Çanakkale Onsekiz Mart Üniversitesi Fen Bilimleri Enstitüsü Dergisi, 2017:3,1, 1-23

Çanakkale Onsekiz Mart University, Journal of Graduate School of Natural and Applied Sciences, 2017:3,1, $1-23$

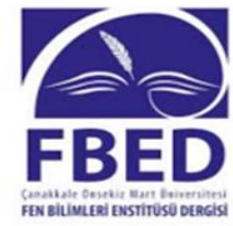

\title{
Deri Atıksuyunun Sono-Elektrokimyasal Arıtımı
}

\author{
İrem Doğu, Mete Yalçın, Burcu İleri*, Önder Ayyıldız \\ Çanakkale Onsekiz Mart Üniversitesi, Mühendislik Fakültesi, \\ Çevre Mühendisliği ABD
}

\section{Özet}

Toksik madde içerikli atıksuların uygun arıtma prosesleri ile arıtıldıktan sonra alıcı ortama deşarj edilmesi çevre kirliliği açısından oldukça önemlidir. Ancak, toksik kirleticilerin gideriminde kullanılan konvansiyonel arıtma yöntemleri çoğu kez yetersiz kalmaktadır. İleri arıtma yöntemlerinin kullanılması durumunda dahi bazen kirletici deşarj standartlarını sağlayacak düzeyde arıtılamamakta veya arıtmanın yüksek maliyetli olmasından ötürü uygulamaları ekonomik olmamaktadır.

Deri endüstrisi atıksuyu yüksek konsantrasyonda kimyasal oksijen ihtiyacı (KOI), biyokimyasal oksijen ihtiyacı (BOI), askıda katı madde (AKM), toplam katı madde (TKM), toplam kjeldahl-azotu (TKN), yağ ve gres, krom(VI), toplam krom, sülfür, tuzluluk, çözünmüş katı madde, organik azot ve toksik metal bileşiklerini içermektedir. Bu tür atık suların, alıcı ortama deşarj edilmeden önce arıtılmaları ve atıksu yönetmeliklerinde belirtilen sınır değerleri sağlayacak şekilde zehirli maddeler ve inhibitörlerden arındırılmaları gerekmektedir. Toksik kirleticilerin gideriminde etkili olmaları ve geniş kullanım alanlarına sahip olmaları nedeniyle ileri arıtma yöntemleri su arıtımında sıklıkla tercih edilmektedir.

\footnotetext{
*Sorumlu Yazar (Corresponding Author): Burcu İleri (e-posta:burcuileri@gmail..com)
}

Burcu İleri'nin, bu çalışması 1919B011500080 No'lu TÜBİTAK 2209-A Üniversite Öğrencileri Yurt İçi Araştırma Projeleri Destek Programı tarafindan desteklenmiştir. 
$\mathrm{Bu}$ çalışmada, deri endüstrisi atıksu örneğinin elektrokimyasal (EC) ve ultrasesin (US) tekli ve birleşik (US/EC) kullanımları ile deri atıksuyun arıtımı sonucunda KOİ, renk ve bulanıklık giderimleri ayrıntılı bir şekilde irdelenmiştir. Alkali şartlarda $(\mathrm{pH}>7)$ yürütülen deneysel çalışmalarda, birleşik US/EC prosesleri ile KOİ, renk veya bulanıklık giderim verimleri tekli uygulamalarından elde edilen giderim veriminden oldukça yüksek olduğu gözlenmiştir.

Anahtar Sözcükler: deri atıksuyu, elektrokimyasal, ultrases

\title{
Sono-Electrochemical Treatment of Leather Wastewater
}

\begin{abstract}
The wastewaters containing high toxic compounds should be treated properly to the extent that can be suitably discharged into receiving waters. Most conventional treatment methods may not be successful for the degradation of recalcitrant compounds presented in water. Even some advance treatment methods remain unsuccessful to bring down their concentrations to the threshold levels.
\end{abstract}

The wastewater from leather industries usually contains high concentration of chemical oxygen demand (COD), biochemical oxygen demand (BOD), suspended solids (TSS), total solids (TS), total kjeldahl-nitrogen, oil-grease, chromium (VI), total chromium, sulfur, salinity, total dissolved matter (TDS), organic nitrogen, and toxic metallic species. Prior to their discharges, such wastewaters should be sufficiently purified from toxic and inhibitory compounds in accordance with water quality guidelines. Advanced oxidation processes have been lately preferred in the treatment of recalcitrant organic compounds due to their effectiveness in the degradation process. 
In this study, wastewater samples from a tanning industry were treated with electrochemical (EC) and ultrasonic (US) processes in both single and combined (US/EC) operations. The effectiveness of the combined US/EC treatment was examined based on COD, color, turbidity removals. For the experiments made at alkaline conditions, the combined US/EC treatment involved synergistic effects providing higher removal efficiencies of COD, color or turbidity than those of additive use of ultrasound and electrochemical processes.

Keywords: electrochemical, leather wastewater, ultrasound

\section{Giriş}

Deri işlenmesi sırasında deriye; ıslatma-yumuşatma, kıl giderme, kireçlik, kireç alma, sama, pikle, tabaklama, nötralizasyon, yağlama, boyama ve dolgu işlemleri gibi birçok işlem uygulanmaktadır. Bu uygulamalar esnasında deride bulunan kirletici ve toksik maddeler suya geçerek kirliliğe sebep olmaktadır. Deri atıksuyu, yüksek konsantrasyonda kimyasal oksijen ihtiyacı (KOİ), askıda katı madde (AKM), toplam kjeldahlazotu (TKN), yağ ve gres, krom(VI), toplam krom, sülfür, tuzluluk, organik yük, çözünmüş katı madde, toplam katı madde, organik azot, toksik metal tuzlar içermektedir.

Ülkemizde yüzeysel su kalite kriterleri ve atıksuların alıcı ortama deşarj standartları 31/12/2004 tarihli ve 25687 sayılı resmi gazetede yayımlanan Çevre ve Orman Bakanlığının çıkartmış olduğu Su Kirliliği Kontrol Yönetmeliği (SKKY)'ne göre belirlenmiştir. İlgili yönetmeliğin Çizelge 1.1' de verilen (deri atıksuları için) KOİ, TKN, yağ-gres, sülfür ve krom parametreleri için deşarj sınır değerlerinin sağlanması gerekmektedir (SKKY, 2004). 
Çizelge 1.1 Deri, deri mamülleri ve benzeri sanayilerin atık sularının alıcı ortama deşarj standartları (SKKY, 2004).

\begin{tabular}{|l|c|c|c|}
\hline \multicolumn{1}{|c|}{ Parametre } & Birim & $\begin{array}{c}\text { Sinır Değer } \\
\text { Kompozit } \\
\text { Numune } \\
\text { (24 Saatlik) }\end{array}$ & $\begin{array}{c}\text { Sinır Değer Kompozit } \\
\text { Numune } \\
\text { (2 Saatlik) }\end{array}$ \\
\hline $\begin{array}{l}\text { Kimyasal Oksijen } \\
\text { İtiyacı (KOİ) }\end{array}$ & $\mathrm{mg} / \mathrm{L}$ & 200 & 300 \\
\hline $\begin{array}{l}\text { Askıda Katı Madde } \\
\text { (AKM) }\end{array}$ & $\mathrm{mg} / \mathrm{L}$ & --- & 125 \\
\hline $\begin{array}{l}\text { Toplam Kjeldahl- } \\
\text { Azotu (TKN) }\end{array}$ & $\mathrm{mg} / \mathrm{L}$ & 15 & 20 \\
\hline Yağ ve Gres & $\mathrm{mg} / \mathrm{L}$ & 20 & 30 \\
\hline Sülfür (S-2) & $\mathrm{mg} / \mathrm{L}$ & 1 & 2 \\
\hline Krom (Cr+6) & $\mathrm{mg} / \mathrm{L}$ & 0,3 & 0,5 \\
\hline Toplam Krom & $\mathrm{mg} / \mathrm{L}$ & 2 & 4 \\
\hline $\begin{array}{l}\text { Balı Biyodeneyi } \\
\text { (ZSF) }\end{array}$ & - & 4 & $6-9$ \\
\hline pH & - & $6-9$ & \\
\hline
\end{tabular}

Deri sanayi atıksularının doğrudan alıcı ortama deşarj edilmesi sonucunda su kalitesi iki farklı şekilde etkilenmektedir. Birincisi, deşarj sonrası suyun çözünmüş oksijen değeri ciddi anlamda azalmakta ve bunun sonucunda oksijene duyarlı canlıların yaşamsal faaliyetleri olumsuz yönde etkilenmektedir. İkincisi, atıksuda bulunan toksik maddeler ani balık ölümlerine neden olmaktadır. Olumsuz çevresel etkileri sebebiyle bu tür atık sular, alıcı ortama deşarj edilmeden önce arıtılmaları ve atık su yönetmeliklerine göre organik ve toksik maddelerden belli oranlarda giderimi sağlanmalıdır. Aksi halde deşarj edildikleri alıcı ortamda suyun oksijenini tüketmekte ve içerdiği toksik maddeler nedeniyle akarsu, göl ve denizlerdeki canlı hayatını tehdit etmektedir. Su ortamında sebep olduğu olumsuz etkiler sebebiyle deri atıksularının arıtımında, koagülasyon-flokülasyon, membran filtrasyonu, kimyasal arıtma, elektrofenton, elektrooksidasyon, biyolojik arıtma, biyolojik arıtma+kimyasal oksidasyon, ozonlama+biyolojik arıtma, iyon değişimi, adsorpsiyon ile ileri oksidasyon proseslerinden ozon, fenton, UV prosesleri yaygın olarak kullanılmaktadır (Apaydın vd., 2009; Kırbaç, 
2010; Ateş, 1997; Y1lmaz, 2013; Şanl1, 2006; Feng vd., 2007; Haydar vd., 2009; Holt vd., 1999; Kurt vd., 2007; Lofrano vd., 2007; Mandal vd., 2010; Preethivd., 2009; Schrank vd., 2005; Song vd., 2001; Yalılı-kılıç vd., 2009).

Elektrokimyasal yöntem, uygun elektrotlar kullanılarak su içerisine elektrik akımı uygulanan bir ileri arıtım prosesidir. Elektrokimyasal arıtım verimi, yüksek oranda su ortamının kimyasına özellikle de iletkenliğine bağlıdır. Ayrıca elektrot tipi, etkin elektrot yüzey alanı, akım yoğunluğu, $\mathrm{pH}$, elektroliz süresi önemli parametreler arasındadır. Elektrokimyasal prosesin işletilmesinde elektrot seçimi oldukça önem arz etmektedir. Alüminyum $\left(\mathrm{Al}^{+3}\right)$ ve demir $\left(\mathrm{Fe}^{+3}, \mathrm{Fe}^{+2}\right)$ elektrotları elektrokimyasal arıtma işlemlerinde en yaygın kullanılan elektrotlardır (Haydar vd., 2009; Mohammed vd., 2009; Holt vd., 2005). Bu elektrotlar prosesin çalışması aşamasında suyla reaksiyona girerek $\mathrm{Al}(\mathrm{OH})_{3}, \mathrm{Fe}(\mathrm{OH})_{2}$ ve $\mathrm{Fe}(\mathrm{OH})_{3}$ gibi metal hidroksitler oluşturmaktadır. Elektrokimyasal arıtım yöntemleri, içme suyu arıtımı ile evsel atıksu, tekstil, boya, mezbaha, süt endüstrisi, sızıntı ve kağıt endüstrisi atıksuları ile deterjan ve maden atıksularının arıtımı gibi birçok alanda uygulanmaktadır (Mohammed vd., 2009; Holt vd., 2005; İlhan vd., 2007; Özyonar ve Karagözoğlu, 2012; Mollah vd., 2001). Elektrokimyasal arıtım yöntemleri, ağır metal, yağ, organik madde, askıda katı madde, renk, nitrat, fenol, arsenik, poliaromatik organik ve lignin kirliliğin gideriminde yaygın olarak kullanılabilmektedir (Mohammed vd., 2009; Holt vd., 2005; İlhan vd., 2007; Özyonar ve Karagözoğlu, 2012; Mollah vd., 2001; Vardar, 2006). Deri atıksu arıtımında kimyasal koagülasyon uygulanan bir çalışmada, askıda katı madde, KOİ ve krom parametrelerinde yüksek oranda giderim verimleri elde edilmiştir (Vardar, 2006). Elektrokoagülasyon kullanılarak deri atıksuyu arıtımında KOİ, renk ve bulanıklık açısından olumlu sonuçlar elde edilmiş ve giderim verimlerinde başlangiç $\mathrm{pH}$, akım yoğunluğu ve elektroliz sürelerinin etkili olduğu belirlenmiştir. Alüminyum elektrotların kullanılmasındaki optimum koşullar irdelenmiş ve bahsedilen parametrelerde \%80'in üzerinde giderim verimleri elde edilmiştir (Apaydın vd., 2009; Şanlı, 2006; 
Kurt vd., 2007). Deri atıksuyu arıtımında elektrofenton oksidasyon prosesinin kullanıldığı bir diğer çalışmada ise, hem KOİ hem de sülfür parametreleri için çok kısa sürede yüksek oranda giderim sağlanmıştır (Holt vd., 1999). Yapılan bir başka çalışmada, fiziksel ve kimyasal olarak arıtılmış deri atık sularında ultrafiltrasyon ve ters osmoz yöntemleri kullanılmıştır. Ters osmoz yönteminin atık suda bulunan yüksek miktardaki klorür nedeniyle geri kazanımda gerekli olduğu ve ultrafiltrasyon prosesinin ise, atık sudaki çözünmüş KOİ giderimin de etkili olmadığı belirtilmiştir (Yalılı-Kılıç vd., 2009).

Ultrases prosesi hem düşük $(20 \mathrm{kHz})$ hem de yüksek frekans (>200 $\mathrm{kHz}$ ) aralıklarında yüksek radikal üretme kapasitesine sahiptir. Ultrasonik dalgaların su içerisinde oluşturdukları kavitasyon kabarcıklarının patlaması sonucunda sıcaklık ve basıncı $\left(5000{ }^{\circ} \mathrm{K}\right.$, 1000 atm) oldukça yüksek olan bir enerji açığa çıkmaktadır. Oluşan kavitasyon kabarcıklarının etkisiyle parçalanan organik bileşikler zararsız yan ürünlere dönüşebilmekte ve bazı radikaller oluşmaktadır. Ultrases etkisiyle oluşan akustik kavitasyon ve şok dalgalar sonucu elektrot yüzeyinden kütle transferi artmakta ve elektron yüzeyi temizlenmektedir. Düşük frekanslı sistemde ultrasesin mekanik etkisi ile elektrot yüzeyi temizlenmekte ve $\bullet \mathrm{OH}, \bullet \mathrm{H}, \bullet \mathrm{HO}_{2}$ gibi radikalleri üretilmektedir. Bunun tersine yüksek frekanslı sistemde yüksek miktarda hidroksil radikali üretimi olurken mekanik etki azalmaktadır.

$\mathrm{H}_{2} \mathrm{O} \stackrel{\text { Us }}{\longrightarrow} \cdot \mathrm{OH}+\bullet \mathrm{H}^{-}$

$\bullet \mathrm{OH}+\bullet \mathrm{OH} \stackrel{\text { US }}{\longrightarrow} \mathrm{H}_{2}{ }^{\bullet}+\mathrm{O}_{2}$

$\bullet \mathrm{H}+\mathrm{O}_{2} \stackrel{U S}{\longrightarrow} \mathrm{H}_{2} \mathrm{O}^{\bullet}$

Birleşik ultrases ve elektrokimyasal oksidasyon sisteminin pek çok organik maddenin giderilmesinde sinerjistik etkiler oluşturduğu bilinmektedir. Atıksuya birlikte uygulandığında, yüksek ultrasonik sıcaklık ve basıncın etkisi altında oluşan kavitasyon kabarcıkları radikallere ayrışmaktadır. Ayrıca, elektrokimyasal arıtma ile elektrottan üretilen $\bullet \mathrm{OH}$ radikalleri ultrasesin tek başına oluşturduğu 
serbest radikallerin bir kısmı ile reaksiyona girerek $\mathrm{H}_{2} \mathrm{O}_{2}$ 'e dönüşmektedir. Oluşan $\mathrm{H}_{2} \mathrm{O}_{2}$ ultrasonik kavitasyon ile tekrar $\bullet \mathrm{OH}$ radikalini üretmektedir (Yang vd., 2014).

$$
\begin{aligned}
& \mathrm{OH}+\bullet \mathrm{OH} \stackrel{())}{\longrightarrow} \mathrm{H}_{2} \mathrm{O}_{2} \\
& \mathrm{H}_{2} \mathrm{O}_{2} \stackrel{())}{\longrightarrow} 2 \cdot \mathrm{OH}
\end{aligned}
$$

İki ayrı proseste üretilen $\bullet \mathrm{OH}$ radikaller elektrokimyasal katalitik oksidasyon prosesinde organik kirleticilerin ayrışmasında önemli rol oynamaktadır. Elektrot yüzeyinde oluşan $\bullet \mathrm{OH}$ radikalleri su içinde hızla yayılarak organik kaynaklı kirleticiler ile reaksiyona girer ve bunun sonucunda $\mathrm{CO}_{2}$ ve $\mathrm{H}_{2} \mathrm{O}$ oluşur. Ultrasonik kavitasyon elektrot yüzeyinden kütle transferinin hızlanmasında sinerjistik etki sağlamaktadır. Ultrasonik şok dalga elektrot yüzeyini temizleyerek kimyasal reaktivite hızlanmakta ve dolayısıyla arıtma verimi artmaktadir.

$\bullet \mathrm{OH}+$ organik kirlilik $\stackrel{\mathrm{l}))}{\longrightarrow} \mathrm{H}_{2} \mathrm{O}+\mathrm{CO}_{2}+$ İnorganik iyon

$\mathrm{Bu}$ araştırma kapsamında, mevcut ileri arıtma yöntemlerine alternatif olarak ultrases (US) ve elektrokimyasal (EC) oksidasyon sistemleri tekli ve birleşik (US/EC) kullanılarak deri endüstrisi atıksularının arıtılmasındaki etkinliği ayrıntılı olarak araştırılmıştır. Çalışmalar kesikli bir reaktör düzeneğinde gerçekleştirilmiştir. Alüminyum elektrot kullanılarak elektrokimyasal işlem ve ultrases ile bu proseslerin birleşik (sono-elektrokimyasal) uygulamaları sonucunda deri atıksuyunun arıtılabilirliği test edilmiştir. US, EC ve birleşik US/EC deneysel çalışmalarında uygun zaman aralıklarında reaktörden alınan örnekler için KOİ, TOK, renk analizleri yapılmıştır. Yürütülen deneysel araştırmalar neticesinde ultrasonik frekans, akım yoğunluğu, elektroliz süresi ve pH'nın arıtma verimine etkileri incelenmiştir. Önerilen arıtma sistemi ile özellikle küçük ölçekli işletmelerden çıkan ve aşırı kirli olmayan deri atıksuyunun deşarj edilebilecek düzeyde arıtılabilmesi hedeflenmiştir 


\section{Materyal ve Metot}

\subsection{Deri atıksuyu karakterizasyonu}

Yapılan çalışmada kullanılan deri atıksuyu, Çanakkale ili Biga ilçesinde bulunan ve deri işleme yapan endüstriye ait atıksu arıtma tesisinden alınmıştır. Numune alındıktan sonra deri atıksuyunun fiziksel-kimyasal karakterizasyonu belirlenmiştir (Çizelge 2.2). Deneyde kullanılan deri atıksu örneği oldukça yüksek KOİ, TOK, bulanıklık, iletkenlik değerlerine sahiptir.

Çizelge 2.2 Deri atıksuyunun fiziksel-kimyasal karakterizasyonu

\begin{tabular}{|l|l|l|}
\hline Parametre & Birimi & Değer \\
\hline KOİ & $\mathrm{mg} / \mathrm{L}$ & 4316 \\
\hline TOK & $\mathrm{mg} / \mathrm{L}$ & 2162 \\
\hline Bulanıklık & $\mathrm{NTU}$ & 9600 \\
\hline İletkenlik & $\mu \mathrm{S} / \mathrm{cm}$ & 22300 \\
\hline $\mathrm{pH}$ & - & 7,8 \\
\hline
\end{tabular}

\subsection{Deney düzeneği}

Deneyler kesikli reaktör düzeneğinde sabit hacim $(1000 \mathrm{~mL})$ ve sıcaklıklarda $\left(20{ }^{\circ} \mathrm{C}\right)$ gerçekleştirilmiştir. Deri atıksu numunelerinin $\mathrm{pH}$ değeri $1 \mathrm{M} \mathrm{NaOH}$ ve $1 \mathrm{M} \mathrm{HCl}$ kullanılarak istenilen başlangıç değerlerine ayarlanmıştır. Elektrokimyasal proses için GW INSTEK, GPS 3030 DD marka ve 0-30 V gerilim ile 0-3 A akım kapasiteli güç kaynağı kullanılmıştır. Elektrokimyasal prosesin işletiminde seçilen elektrotun türü oldukça önemlidir. Yapılan çalışmada alüminyum elektrot plaka kullanılmıştır. Metal alüminyum elektrot boyutları, $2 \mathrm{~mm}$ x $6 \mathrm{~cm}$ x $7,5 \mathrm{~cm}$, etkin yüzey alanı 45 $\mathrm{cm}^{2}$, dir. Elektrokimyasal arıtmada kullanılan alüminyum elektrodu koagülant şeklinde reaksiyon gerçekleştirmektedir. Alüminyum elektrotlar anot ve katot olarak paralel bağlı şekilde deneylerde kullanılmıştır. Yüksek frekanslı ultrases cihazı bir jeneratör 
ve transdüserden oluşmaktadır. Deneysel çalışmalarda ultrases sistemi 582, 864 ve $1144 \mathrm{kHz}$ olarak 3 farklı frekans aralığında çalıştırılmıştır. Deri atıksu arıtımında kullanılan sono-elektrokimyasal deney düzeneği Şekil 2.1'de şematik olarak gösterilmiştir.

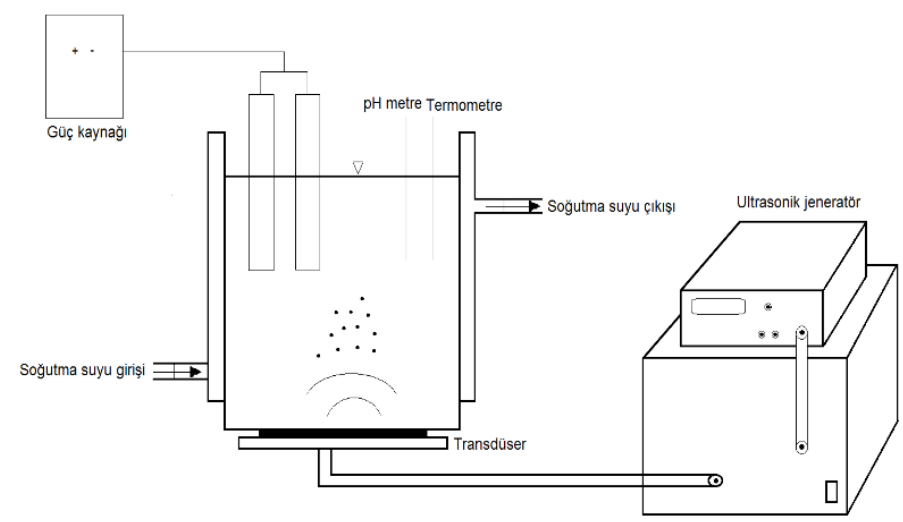

Şekil 2.1. Sono-elektrokimyasal deney düzeneği

Güç kaynağı üzerinde istenen akım ve voltaj ayarlaması yapıldıktan sonra ultrasonik jeneratöre bağlı reaktör içine 2 adet alüminyum elektrodu reaktör tabanına dikey biçimde yerleştirilerek sabitlenmiştir. Akım ve voltaj ayarlaması için suya tuz $(\mathrm{NaCl})$ ilavesi yapılmıştır. Farklı ultrasonik frekans, akım yoğunluğu, elektroliz süresi ve $\mathrm{pH}$ parametrelerinin sistem performansına etkisi incelenmiştir. Belirli zaman aralıklarında reaktörden örnek alınarak KOİ, TOK, bulanıklık ve renk analizleri yapılmıştır. KOİ analizi standart metoda göre kapalı reflux yöntemi ile; bulanıklık tayini türbidimetre ile (Hach-Turbidimeter $2100 \mathrm{AN}$ ); renk analizi UV-spektrofotometre ile (Hach-Lange 5000); TOK ölçümü ise 505-TOCTN (Hach-Lange) model cihaz kullanılarak yapılmıştır.

\section{Bulgular ve Tartışma}

\subsection{Başlangıç pH'nın etkisi}

Su ve atıksuların elektrokoagülasyon yöntemi ile arıtılmasında $\mathrm{pH}$, arıtma performansını ve metal hidroksitlerin çözünürlüğünü 
etkileyen önemli bir parametredir. Anot ve katot reaksiyonlarının sulu çözelti içerisindeki reaksiyonları sonucu çözeltinin pH's1 değişmektedir. Elektrokoagülasyonda anot olarak demir veya alüminyum elektrotlar kullanılması halinde bu elektrotlar çözünerek çözeltiye $\mathrm{Al}^{3+}, \mathrm{Fe}^{2+}$ ve $\mathrm{Fe}^{3+}$ iyonları vermekte ve bu iyonlar sudaki hidroksit iyonları ile birleşerek çok az çözünen $\mathrm{Al}(\mathrm{OH})_{3}, \quad \mathrm{Fe}(\mathrm{OH})_{2}$ ve $\mathrm{Fe}(\mathrm{OH})_{3}$ gibi metal hidroksitler oluşturmaktadır. $\mathrm{Bu}$ çalışmada $\mathrm{Al}$ elektrot kullanılmış ve $\mathrm{pH}$ değerine bağlı olarak alüminyum için hidroksit oluşma reaksiyonları aşağıda verilmiştir (Chen, 2004).

Anotta:

$\mathrm{Al}+3 \mathrm{e}^{-} \longrightarrow \mathrm{Al}^{+3}$

Çözeltide:

$\mathrm{Al}^{+3}+3 \mathrm{OH}^{-} \longrightarrow \mathrm{Al}(\mathrm{OH})_{3}$

$\mathrm{Al}^{+3}+3 \mathrm{H}_{2} \mathrm{O} \longrightarrow \mathrm{Al}(\mathrm{OH})_{3}+3 \mathrm{H}^{+}$

Bununla birlikte sulu ortamın $\mathrm{pH}$ değerine bağlı olarak reaksiyon sonucunda $\mathrm{Al}(\mathrm{OH})_{2}{ }^{+}, \mathrm{Al}(\mathrm{OH})^{+2}$ ve $\mathrm{Al}(\mathrm{OH})_{4}{ }^{-}$gibi diğer bazı alüminyum birleşik türleri oluşmaktadır (Özcan vd., 2014). Çok asidik veya çok bazik pH değerlerinde alüminyum metal hidroksit çözünürlüklerinde belirgin artışlar meydana gelerek yumak oluşumunda ciddi azalmalar söz konusu olmaktadır. Alüminyum elektrotların akım verimleri nötr koşullara göre asidik veya alkali koşullarda daha yüksek olmaktadır (Özyonar ve Karagözoğlu, 2012). $\mathrm{Bu}$ çalışmada, başlangıç $\mathrm{pH}$ değerinin elektrokimyasal prosese etkisini belirlemek amacıyla deri atıksuyu örneğinin $\mathrm{pH}$ değeri istenilen aralığa $1 \mathrm{M} \mathrm{NaOH}$ ve $1 \mathrm{M} \mathrm{HCl}$ kullanılarak ayarlanmıştır. Dört, 6, 8 ve 10 olmak üzere 4 farklı pH aralığında deneyler yürütülmüştür (Şekil 3.1A-B). EC proseste alüminyum elektrotlar kullanılarak 10 volt, $1 \mathrm{~A} / \mathrm{m}^{2}$ akım yoğunluğu ve 30 dakika elektroliz süresinde deneyler yürütülmüştür. Alüminyum elektrotlarının kullanıldığı elektrokimyasal deneylerde KOİ, TOK ve renk giderim 
verimi üzerine başlangıç $\mathrm{pH}$ değerinin etkisi Şekil 3.1A-B'de gösterilmiştir.

Şekil 3.1. Elektrokimyasal proseste başlangıç pH değerinin KOİ, TOK ve renk giderim verimine etkisi $\left(\mathrm{A}=1 \mathrm{~A} / \mathrm{m}^{2}, \mathrm{~V}=10\right.$ volt $)$
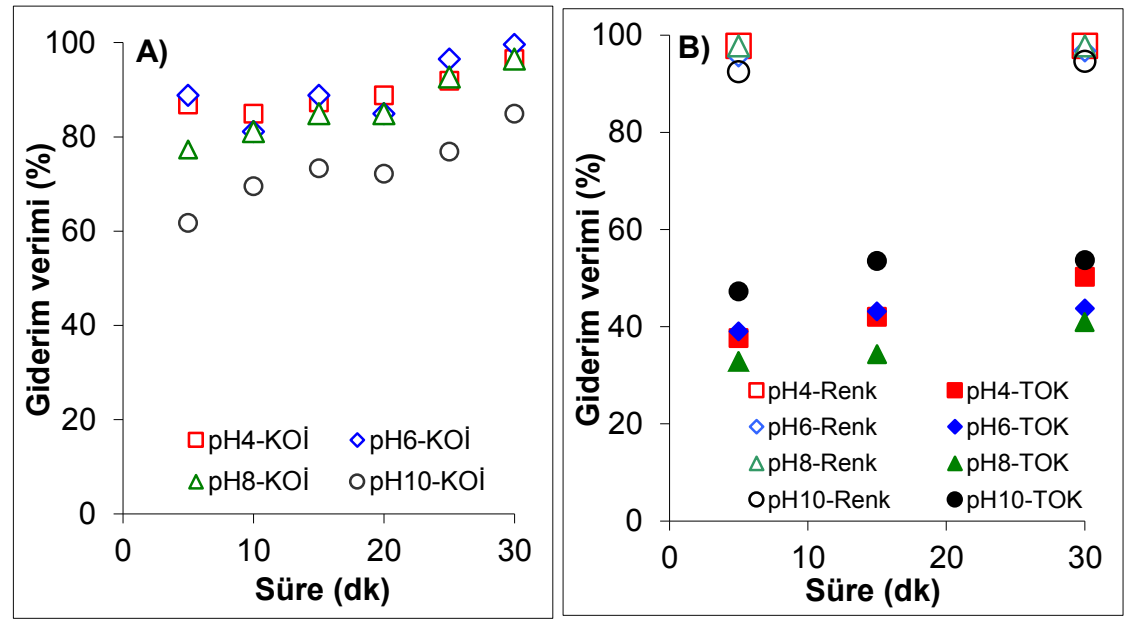

$30 \mathrm{dk}$ reaksiyon süresi sonunda asidik $\mathrm{pH}$ değerlerinde ( $\mathrm{pH} 4$ ve 6$)$ KOİ ve TOK giderim verimleri sirasiyla \%96-99 ile \%40-50 arasinda iken; $\mathrm{pH}$ değeri bazik ( $\mathrm{pH} 8$ ve 10) olduğunda KOİ ve TOK giderim verimleri sirasıyla $\% 85-96$ ve \%41-53 olarak belirlenmiştir. $\mathrm{pH}$ değeri arttıkça KOİ giderim verimi azalmıştır. Alüminyum elektrotlarla yürütülen elektrokimyasal arıtma uygulamalarının yaklaşık ilk 5 dakikasında ise rengin tamamı giderilmiştir. Literatürde demir elektrotlar için optimum $\mathrm{pH} 6^{-9}$ arasında iken alüminyum için ise $\mathrm{pH} 6$ olarak verilmektedir. Optimum pH'nın belirlenmesi amaciyla alüminyum elektrotlar ile yürütülen deneylerden elde edilen sonuçlarda en yüksek KOİ giderme verimleri asidik $\mathrm{pH}$ değerlerinde gözlenmiştir (Şanlı, 2006). Ancak suyun asit türevleriyle kirletilmesini önlemek amacıyla deneysel çalışmalar $\mathrm{pH}$ kontrolsüz olarak yürütülmüş̧ür. Elektrokimyasal arıtma uygulamaları esnasında $\mathrm{pH}$ değişimleri incelendiğinde $\mathrm{pH}$ 'nın zamana bağlı olarak arttığı ve reaksiyon sonunda ölçülen $\mathrm{pH}$ değerinin daima başlangıç $\mathrm{pH}$ değerinden daha yüksek olduğu gözlenmiştir. 


\subsection{Elektroliz süresinin etkisi}

Elektrokoagülasyonda elektroliz sonucu anotun çözünmesi ile ar1tımı sağlanan atıksu içerisinde metal hidroksit floklarının oluşması arıtma süresine göre değişmektedir. Elektroliz süresinin arttırılması ile suda iyon konsantrasyonu ve hidroksit formları artmaktadır. Tüm arıtma işlemlerinde olduğu gibi, arıtma süresinin mümkün olduğunca kısa tutulması uygulanan yöntemin pratik uygulamaları açısından oldukça önemlidir. Arıtım süresinin optimizasyonu sağlanamazsa hem işletim maliyeti artar hem de uzun süreli yapılan arıtma işlemi sonucunda fazla miktarda çamur ve köpük oluşur. Faraday Yasası'na göre akım yoğunluğunun artması ile anotta çözünen madde miktarı da artmaktadır. Akım yoğunluğunun artması ayrıca enerji tüketimini de artırmaktadır. Diğer taraftan, uygulanan akım yoğunluğuna bağlı olarak elektroliz süresinin artması ile oluşan hidroksit miktarı da artmaktadır (Özyonar vd., 2011). Deri atıksuyunun elektrokimyasal (Al elektrot) arıt1lmas1 sonucunda elektroliz süresine bağlı elde edilen KOİ giderim oranları Şekil 3.2'de gösterilmiştir. Şekil 3.2'den de anlaşılacağı üzere, elde edilen KOİ giderim verimlerine göre optimum elektroliz süresi belirlenmiştir. Elektrokimyasal yöntemle KOİ giderim verimi hızlı bir şekilde artmıştır. Beş dakikadan az bir süre zarfında KOİ giderim verimi $\% 45$ civarına ulaşmış ve akabinde giderim hızı zamanla azalarak $30 \mathrm{dk}$ 'dan sonra sabit kalmıştır. Elektrokimyasal proses için reaksiyonun ağırlıklı olarak ilk 10-20 dk aralığında gerçekleştiği görülmüştür. Bu veriler ışığında tüm deneysel çalışmalar için azami elektrolit süresi $30 \mathrm{dk}$ olarak belirlenmiştir. Elektroliz süresi arttıkça suda oluşan Al elektrotta oluşan iyon miktarı arttıkça $\mathrm{Al}(\mathrm{OH})_{3}$ katı oluşumu da artmıştır. Arıtma sürenin $30 \mathrm{dk}$ 'dan daha fazla olduğu durumlarda KOİ giderim verimi süresinin artması ile elektrot yüzeyi oksit tabaka ile kaplanmış ve elektrottan çözünerek suya geçen alüminyum iyon miktarı zamanla azaldığı için verim değişmemiştir. 


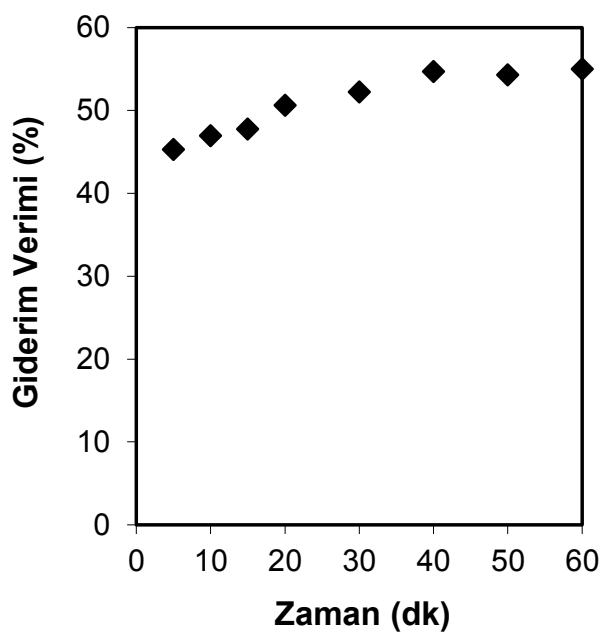

Şekil 3.2. Elektroliz süresinin KOİ giderimine etkisi $\left(A=1 \mathrm{~A} / \mathrm{m}^{2}\right.$; $\mathrm{V}=10$ volt; $\mathrm{pH}=7,8$ )

\subsection{Akım yoğunluğunun etkisi}

Elektrokimyasal yöntemle kirleticilerin arıtımında önemli olan parametrelerden birisi de akım yoğunluğudur. Sisteme uygulanan akım şiddetine bağlı olarak elektrotlardan çözünen (anot elektrot) metal miktarı değişmektedir. Özellikle su ve atıksu arıtımında oluşan kirleticilerin giderimi yüksek akım yoğunluğunda oluşan metal hidroksit miktarının artması ile artmaktadır. Elektrokimyasal prosesler için çözeltinin iletkenliği önemli bir parametredir. Suyun iletkenliği artıkça elektrik akımını iletme kapasitesi de artmaktadır. Ancak suyun iletkenliği yeterli olmadığı durumlarda, elektrolit olarak suya tuz $(\mathrm{NaCl}, \mathrm{KCl} \mathrm{vb})$ ilave edilerek suyun elektrik ak1mını iletme kapasitesi artırılmaktadır. Bu nedenle deneylerde akım değerini 1 veya $1,5 \mathrm{~A}$ civarına yükseltmek için örneklere $\mathrm{NaCl}$ ilave edilmiştir. İlk olarak deneyler $\mathrm{pH}$ kontrolsüz $(\mathrm{pH}=7,8)$ olarak, farklı akım yoğunluğu değerlerinde $\left(1 \mathrm{~A} / \mathrm{m}^{2}, 2 \mathrm{~A} / \mathrm{m}^{2}\right.$ ve 3 $\left.\mathrm{A} / \mathrm{m}^{2}\right) 30 \mathrm{dk}$ elektroliz süresince elektrokimyasal arıtma işlemi gerçekleştirilmiştir. Şekil 3.3' de gösterildiği gibi $1 \mathrm{~A} / \mathrm{m}^{2}, 2 \mathrm{~A} / \mathrm{m}^{2} \mathrm{ve}$ 
$3 \mathrm{~A} / \mathrm{m}^{2}$ akım yoğunluğunda sırasıly $\% 88, \% 95$ ve $\% 92$ KOİ giderim verimleri elde edilmiştir.

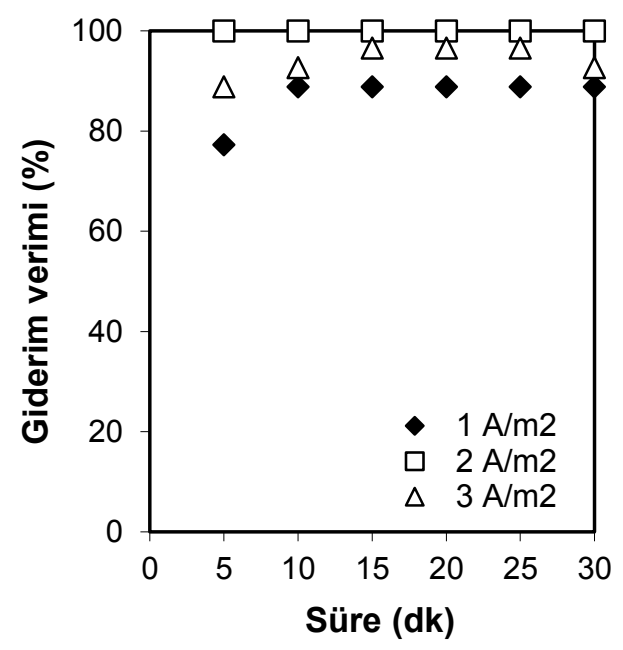

Şekil 3.3. Akım yoğunluğunun KOİ giderimine etkisi (V=10 volt; $\mathrm{pH}=7,8$ )

Özyonar ve Karagözoğlu (2012) tarafından yürütülen bir çalışmada, EC prosesi ile evsel atıksudan bulanıklık gideriminde akım yoğunluğunun etkisi $2,5-40 \mathrm{~A} / \mathrm{m}^{2}$ aralığında irdelenmiştir. Alüminyum ve demir elektrotlarının kullanıldığ $\mathrm{EC}$ deneylerinde en yüksek giderim verimi $\% 95,78$ ve $\% 87,80$ ile $10 \mathrm{~A} / \mathrm{m}^{2}$ akım yoğunluğunda elde edilmiştir. İki buçuk $-10 \mathrm{~A} / \mathrm{m}^{2}$ aralığında giderim veriminde artış olduğu, ancak $10 \mathrm{~A} / \mathrm{m}^{2}$ akım yoğunluğundan daha yüksek uygulandığında katotta oluşan $\mathrm{H}_{2}$ 'nın flotasyonu hızlandırması ve hızla oluşan $\mathrm{Me}(\mathrm{OH})_{3}$ koagülantların kirletici gideriminde fazla etkili olmaması sebebiyle giderim verimi azalmamıştır.

Elektrokimyasal arıtma uygulamasında $\mathrm{NaCl}$ hem iletkenliği artırmakta hem de güçlü oksitleyicilerin oluşumuna katkı sağlamaktadır. Böylece koagülasyon ile oksidasyonun sinerjik etkisini görebilmek mümkün olmaktadır. Ancak, $\mathrm{NaCl}$ konsantrasyonunun fazla olması elektrotların daha fazla çözünmesine neden olmakta ve dolayısıyla da çamur oluşumunu artırmaktadır. Kullanılan 
elektrokimyasal jeneratör ile tuz ilavesi olmadan ancak $1 \mathrm{~A} / \mathrm{m}^{2}$ civarında bir akım yoğunluğu sağlanabilmektedir. Deneysel çalışmaların bundan sonraki bölümünde optimum akım yoğunluğu 1 $\mathrm{A} / \mathrm{m}^{2}$ seçilmiş ve ultrases uygulamalarında $1 \mathrm{~A} / \mathrm{m}^{2}$ akım uygulanmiştır.

\subsection{UItrasonik frekansın etkisi}

Deri işleme faaliyetleri sonucunda oluşan atıksular yüksek konsantrasyonlarda organik bileşikler içermektedir. Deri atıksuyu deşarjı için genellikle KOİ, renk, krom gibi bu parametreler dikkate alınmaktadır. Bu amaçla, organik kirliliğin giderilmesinde elektrokimyasal sistem ile ultrases birleşik olarak uygulanmıştır.

Ultrasonik cihaz 582, 864, $1144 \mathrm{kHz}$ frekanslarında kullanılmıştır. Ultrases uygulamalarında sicaklık kontrolü soğutmalı su banyosu kullanılarak sağlanmıştır. Sadece elektrokimyasal ve sono-elektrokimyasal arıtma yöntemleri ile elde edilen KOİ giderim verimleri Şekil 3.4A-B' de gösterilmiştir. Elektrokimyasal deneyler $1 \mathrm{~A} / \mathrm{m}^{2}$ akım yoğunluğu ve bazik pH değerinde yürütülmüştür. Elektrokimyasal arıtma sonucunda KOİ giderim verimi $30 \mathrm{dk}$ elektroliz süresi sonunda yaklaşık \%85 civarında elde edilmiştir. Beş yüz seksen iki, 864 ve $1144 \mathrm{kHz}$ frekanslarda gerçekleştirilen sonoelektrokimyasal arıtma işlemleri sonucunda ise sırasıly \%97, $\% 100$ ve \%100 civarında KOİ giderimi sağlanmıştır (Şekil 3.4A). 

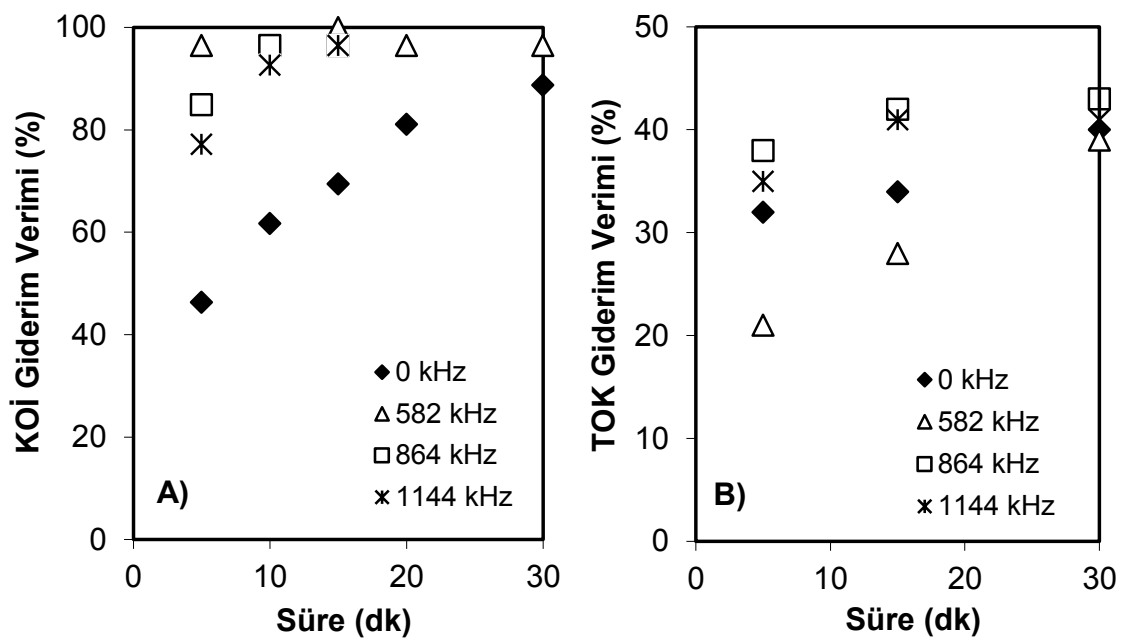

Şekil 3.4. Ultrasonik frekansın KOİ ve TOK giderimine etkisi $(\mathrm{A}=$ $1 \mathrm{~A} / \mathrm{m}^{2} ; \mathrm{V}=10$ volt; $\mathrm{pH}=7,8$ )

TOK giderim verimleri 582, 864, $1144 \mathrm{kHz}$ frekanslarda sirasıly $\% 32, \% 39$ ve $\% 40$ olarak elde edilmiştir (Şekil 3.4B). Renk ve bulanıklık giderimleri ise \%95-100 aralığında belirlenmiştir. Birleşik ultrases ve elektrokimyasal oksidasyon (US/EC) sisteminin atıksuya birlikte uygulandığında ultrasonik sıcaklık ve basıncın etkisi altında oluşan kavitasyon kabarcıkları radikallere ayrışmaktadır. Ayrıca elektrokimyasal aritma ile elektrottan üretilen $\bullet \mathrm{OH}$ radikalleri ultrasesin tek başına oluşturduğu serbest radikallerin bir kısmı ile reaksiyona girerek $\mathrm{H}_{2} \mathrm{O}_{2}$ 'e dönüşmektedir. Oluşan $\mathrm{H}_{2} \mathrm{O}_{2}$ ultrases kavitasyon etkisiyle tekrar $\bullet \mathrm{OH}$ radikali oluşturmaktadır (Yang vd., 2014). İki ayrı proseste üretilen $\bullet O H$ radikaller elektrokimyasal katalitik oksidasyon prosesinde organik kirleticilerin ayrışmasında önemli rol oynamaktadır. Ultrasonik kavitasyon elektrot yüzeyinde oluşan $\bullet \mathrm{OH}$ radikallerinin suya geçişini hızlandırmakta ve böylece organik maddenin giderilmesinde sinerjistik etkiyi artırmaktadır. Elektrot yüzeyinde oluşan iyonlar ve $\bullet \mathrm{OH}$ radikalleri su içinde hızla yayılarak organik kaynaklı kirleticileri aşağıda gösterildiği gibi $\mathrm{CO}_{2}$ ve $\mathrm{H}_{2} \mathrm{O}$ moleküllerine ayrıştırmaktadır. 
$\mathrm{OH}+\mathrm{OH} \rightarrow \mathrm{H}_{2} \mathrm{O}_{2}$

$\mathrm{H}_{2} \mathrm{O}_{2} \stackrel{\mathrm{\prime})}{\longrightarrow} 2 \mathrm{OH}$

$\mathrm{OH}+$ organik kirlilik $\stackrel{\mathrm{l})}{\longrightarrow} \mathrm{H}_{2} \mathrm{O}+\mathrm{CO}_{2}+$ İnorganik iyon

Ultrases, EC ve US/EC proseslerinin tek ve birleşik uygulamaları sonucu optimum ultrasonik frekans $582 \mathrm{kHz}$ olarak belirlenmiş ve bu frekans için KOİ ve TOK giderim verimleri Şekil 3.5A-B' de gösterilmiştir.
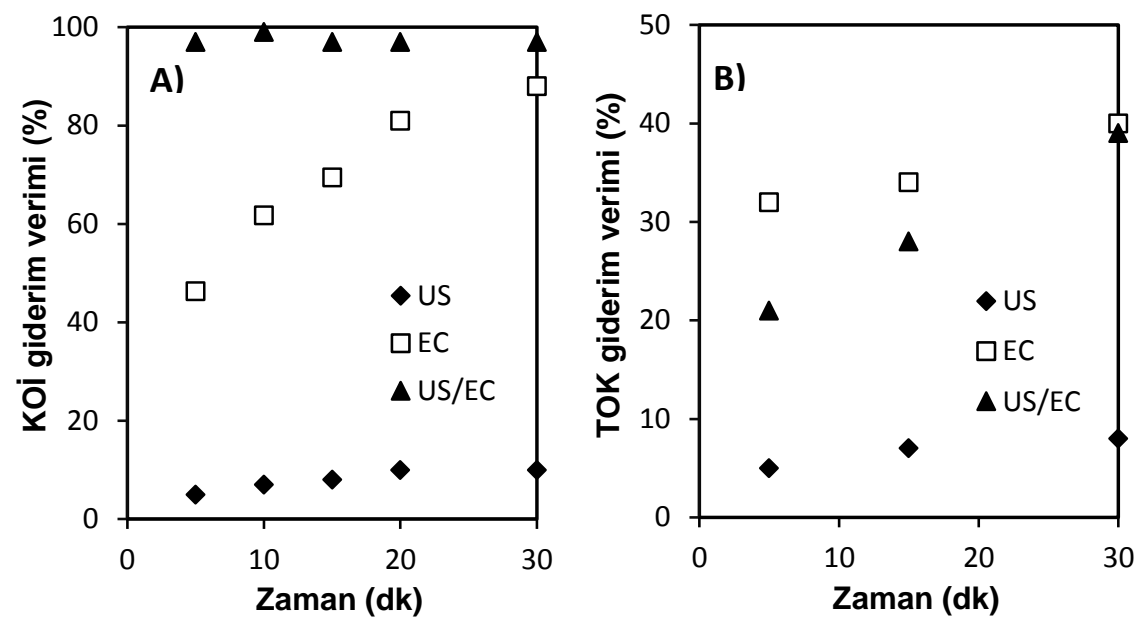

Şekil 3.5. Ultrases ve elektrokimyasal prosesinin KOİ ve TOK giderimine etkisi (US= $582 \mathrm{kHz} ; \mathrm{A}=1 \mathrm{~A} / \mathrm{m}^{2} ; \mathrm{V}=10$ volt; $\mathrm{pH}=7,8$ )

Yalnız US ile yapılan deneyde giderim oldukça düşük iken, $1 \mathrm{~A} / \mathrm{m}^{2}$ akım yoğunluğunda elektrokimyasal proseste $30 \mathrm{dk}$ elektroliz süresi sonunda \%88 KOİ ve \%40 TOK giderimi elde edilmiştir. Sono-elektrokimyasal uygulama sonucu (US/EC) KOİ giderimi \%97 iken TOK giderimi \%40 olarak belirlenmiştir. Birleşik sonoelektrokimyasal sisteminin KOİ gideriminde gösterdiği sinerjistik etkinin bu iki proseste oluşan $\bullet \mathrm{OH}$ radikalleri ve ultrasesin elektrot yüzey temizleme etkisinden kaynaklandığı düşünülmektedir. Elde 
edilen sonuçlara göre, sono-elektrokimyasal proses uygulandığında giderim verimi artmakta ve hatta KOİ değeri deşarj standart değerinin altına düşürülebilmektedir.

\section{Sonuç}

Yürütülen bu çalışmada, sadece elektrokimyasal ve ultrases ile bu proseslerin birleşik sono-elektrokimyasal deri atıksuyu örneklerine uygulandığı durumlarda TOK, KOİ, bulanıklık ve renk giderim verimleri kapsamlı bir şekilde irdelenmiş̧ir. Çalışmada pH'nın elektrokimyasal proses ile deri atıksuyu arıtımına etkisi test edilmiştir. Deri atıksuyunun elektrokimyasal prosesi ile arttılmasında $(\mathrm{pH}=$ 6-8), $1 \mathrm{~A} / \mathrm{m}^{2}$ akım yoğunluğu ve $30 \mathrm{dk}$ elektroliz süresi uygulamas1 sonucunda $\% 85$ KOİ giderim verimi elde edilmiştir. Ultrasonik arıtma 582, 864, $1144 \mathrm{kHz}$ frekanslarda tek başına uygulandığında çok düşük oranlarda KOİ veya renk giderimi elde edilebilmiştir. Ultrases ve elektrokimyasal proseslerin birleşik uygulamalarında ise 582, 864, $1144 \mathrm{kHz}$ frekanslarda sirasıyla KOİ, renk ve bulanıklık için $\% 97, \% 100$ ve $\% 100$ oranlarında giderim verimleri sağlanmıştır. Elde edilen sonuçlara göre, sono-elektrokimyasal yöntemle deri atıksuyunun KOİ değeri deşarj standartlarının altına düşürülebilmektedir.

\section{Teşekkür}

Bu çalışma 1919B011500080 No'lu TÜBİTAK 2209-A Üniversite Öğrencileri Yurt İçi Araştırma Projeleri Destek Programı tarafından desteklenmiştir.

\section{Kaynaklar}

Apaydın Ö., Kurt U., Gönüllü M.T., 2009. An Investigation on the Treatment of Tannery Wastewater by Electrocoagulation, Global Nest J., 11 (4), 546-555. 
Ateş G.E., 1997. Deri Endüstrisi Atıksularının Biyolojik Arıtılabilirliği ve Kinetik Karakterizasyonu, İstanbul Teknik Üniversitesi, Fen Bilimleri Enstitüsü, Doktora Tezi, İstanbul.

Chen G., 2004. Electrochemical Technologies in Wastewater Treatment, Separation and Purification Technology, 38 (1), 1141.

Feng J., Sun Y., Zheng Z., Zhang J., LI S., Tian Y., 2007. Treatment of Tannery Wastewater by Electrocoagulation, Journal of Environmental Sciences, 19 (12), 1409-1415.

Haydar S., Aziz J. A., 2009. Coagulation-Flocculation Studies of Tannery Wastewater Using Combination of Alum with Cationic and Anionic Polymers, Journal of Hazardous Materials, 168 (2-3), 1035-1040.

Holt P., Barton G., ve Mitchell C., 1999. Electrocoagulation as a Wastewater Treatment. The Third Annual Australian Environmental Engineering Research Event, 23-26.

Holt P.K., Barton, G.W., Mitchell, C.A., 2005. The Future for Electrocoagulation as a Localised Water Treatment Technology, Chemosphere, 59 (3), 55-367.

İlhan F., Kurt U., Apaydın Ö., Arslankaya E., Gönüllü M.T., 2007. Elektrokimyasal Arıtım ve Uygulamaları: Katı Atık Sızıntı 
Suyu Çalışması. TÜRKAY, AB sürecinde Türkiye'de Katı Atık Yönetimi ve Çevre Sorunları Sempozyumu.

Kırbaç E., 2010. Endüstriyel Atıklarda Boya Maddelerinin Elektrokoagülasyonla Uzaklaştırılması, Sakarya Üniversitesi Fen Bilimleri Enstitüsü, Yüksek Lisans Tezi, Sakarya.

Kurt U., Apaydın Ö., Gönüllü M.T., 2007. Reduction of COD in Wastewater from an Organized Tannery Industrial Region by Electro-Fenton Process, Journal of Hazardous Materials, 143 (1-2), 33-40.

Lofrano G., Meriç S., Belgiorno V., Napoli R.M.A., 2007. Fenton's Oxidation of Various-based Tanning Materials, Desalination, 211 (1-3), 10-21.

Mandal T., Dasgupt D., Mandal S., Datta S., 2010. Treatment of Leather İndustry Wastewater by Aerobic Biological and Fenton Oxidation Process, Journal of Hazardous Materials, 180 (1-3), 204-211.

Mohammed M.E., Sivakumar M., 2009. Review of Pollutants Removed by Electrocoagulation and Electrocoagulation/Flotation Processes. Journal of Environmental Management, 90 (5), 1663-1679. 
Mollah M.Y., Schennach, R., Parga, J.R., Cocke, D.L., 2001. Electrocoagulation(EC)-Science and Applications, Journal of Hazardous Materials, B84, 29-41.

Özcan S., Yılmaz M. T., Bayar S., 2014. Erzurum Şeker Fabrikası Atıksularının Elektrokoagülasyon Prosesi ile Arıtılmasında Akım yoğunluğu ve Karıştırma Hızının Etkisi, Iğdır Üniversitesi Fen Bilimleri Dergisi, 4 (4), 57-65.

Özyonar F., Karagözoğlu B., 2012. Elektrokoagülasyon Prosesi ile Tekstil Sanayi Atıksuyunun Arıtımı, Erciyes Üniversitesi Fen Bilimleri Enstitüsü Dergisi, 28 (1), 29-37.

Özyonar F., Karagözoğlu B., 2012. İçme Sularından Elektrokoagülasyon ve Kimyasal Koagülasyon ile Bulanıklı̆̆ın Giderimi, Gazi Üniv. Müh. Mim. Fak. Der., 27 (1), 81-89.

Özyonar F., Karagözoğlu B., Atmaca E., 2011. İçme suyundan Elektrokoagülasyon Prosesi ile Doğal Organik Madde Giderimi, Erciyes Üniversitesi Fen Bilimleri Enstitüsü Dergisi, 27 (4), 309-316.

Preethi V., Parama Kalyani K.S., Iyappan K., Srinivasakannan C., Balasubramaniam N., Vedaraman, N., 2009. Ozonation of Tannery Effluent for Removal of COD and Color, Journal of Hazardous Materials, 166 (1), 150-154. 
Schrank S.G., José H.J., Moreira R.F.P.M., Schröder H.Fr., 2005. Applicability of Fenton and $\mathrm{H}_{2} \mathrm{O}_{2} / \mathrm{UV}$ Reactions in the Treatment of Tannery Wastewaters, Chemosphere, 60 (5), 644655.

Song Z., Williams C.J., Edyvean R.G.J., 2001. Coagulation and Anaerobic Digestion of Tannery Wastewater, Process Safety and Environmental Protection, 79 (1), 23-28.

Su Kirliliği Kontrolü Yönetmeliği, 2004. 31.12.2004 tarih ve 25687 say1lı Resmi Gazete, Ankara.

Şanlı N., 2006. Deri Sanayi Atıksularının Kimyasal Koagülasyon ve Elektrokoagülasyon ile Arıtımı, Gebze İleri Teknoloji Enstitüsü, Mühendislik ve Fen Bilimleri Enstitüsü, Yüksek Lisans Tezi, Kocaeli.

Şen M.F., 2007. Katı Atık Sızıntı Sularının Elektrokimyasal Yöntemler İle Arttılabilirliğinin İncelenmesi, Gebze İleri Teknoloji Enstitüsü, Mühendislik ve Fen Bilimleri Enstitüsü, Yüksek Lisans Tezi, Kocaeli.

Vardar B., 2006. Tekstil Endüstrisi Reaktif Boya Banyolarının Elektrokimyasal Yöntemler İle Arıtımı, İTÜ, Fen Bilimleri Enstitüsü, Yüksek Lisans Tezi, İstanbul. 
Yalıl1-Kılıç M., Kırıl-Mert B., Kestioğlu K., 2009. Deri Atıksularının Arıtımında Kimyasal Arıtma ve Adsorpsiyon Yöntemlerinin Uygulanması, Frrat Üniversitesi Fen Bilimleri Dergisi, 21 (2), 95-101.

Yang B., Zuo J., Tang X., Liu F., Yu X., Tang X., Jiang H., Gan L., 2014. Effective Ultrasound Electrochemical Degradation of Methylene Blue Wastewater using A Nanocoated Electrode, Ultrasonic Sonochemistry, 21 (4), 1310-1317.

Yılmaz S., 2013. İçki Sanayi (Alkolsüz İçkiler, Meşrubat Üretimi vs.) Sirke Kimyasal-Elektrokimyasal Koagülasyonu ve Nano Kaplamalı Elektrotlar İle Arıtımı, Anadolu Üniversitesi, Fen Bilimleri Enstitüsü, Yüksek Lisans Tezi, Eskişehir. 